\title{
REVISTAMARACANAN
}

\section{A participação de Octavio Corrêa na Revolta dos 18 do Forte de Copacabana}

\section{Resenha de:}

LICKS, Afonso. Octavio, o civil entre os 18 do Forte de Copacabana. Porto Alegre: Quattro Projetos, 2016, 144 p.

\section{Lucas Godoy Stringuetti*}

Universidade Estadual Paulista - Campus de Assis,

Brasil.

Recebido em: 31 dez. 2018.

Aprovado em: 3 abr. 2019.

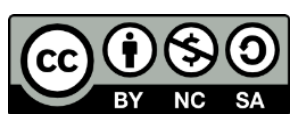

Palavras-chave: Biografia. Revolta dos Dezoito do Forte. Octavio Corrêa.

Keywords: Biography. Eighteen of the Copacabana Fort Revolt. Octavio Corrêa.

O presente trabalho foi realizado com apoio da Coordenação de Aperfeiçoamento de Pessoal de Nível Superior - Brasil (CAPES) - Código de Financiamento 001. Ele configura-se, igualmente, como complemento aos requisitos necessários à escrita da Tese de Doutorado em História e Sociedade pela Universidade Estadual Paulista, Campus de Assis.

* Doutorando em História e Sociedade, com bolsa da CAPES, Pelo Programa de Pós-graduação em História da Universidade Estadual Paulista, Campus Assis (UNESP/Assis). Mestre em História e Sociedade pela UNESP/Assis; graduado em História pela UNESP/Assis.

ORDCID iD: https://orcid.org/0000-0001-9683-7873

CV Lattes: http://lattes.cnpq.br/4402566368145163 
A presente obra foi escrita por Roberto Licks, nascido em Montenegro, Rio Grande do Sul, em 1953. O autor é advogado, jornalista, com atuação em rádio, jornal, TV, revista e agência de notícias. O escritor traz a público um trabalho inédito, contribuindo para a história do Brasil República, a respeito de Octavio Augusto da Cunha Corrêa, apelidado de Moreno Corrêa, o único civil morto entre os Dezoito do Forte de Copacabana, em 1922, no Rio de Janeiro.

Licks, mesmo não sendo historiador, realiza um trabalho com farta investigação em documentos escassos, livros, jornais e em depoimentos, com a intenção de desvendar a vida daquele que foi o único civil a participar da última marcha para a morte em 1922, vindo a falecer aos 36 anos e que até então não havia despertado interesse pela historiografia brasileira. Cabe ressaltarmos que a imagem dos Dezoito do Forte de Copacabana, após o episódio, foi elevada a exemplo patriótico, seus participantes foram vistos como heróis, tendo seus nomes atribuídos a praças e ruas pelo país.

Para Licks, Corrêa, nascido em Quaraí, Rio Grande do Sul, sequer tem o nome grafado de forma correta nas placas que o homenageiam. Sua imagem acabou desaparecendo, os registros comuns se referem a ele como um engenheiro, advogado, um capitalista, um maluco que surgiu do nada para ir morrer num combate que não era seu.

Em 1922, a Revolta tenentista, ocorrida na tarde de 6 de julho, reuniu um grupo de jovens tenentes que não tinham um plano político claro, diferente, por exemplo, do movimento tenentista posterior, que ocorreu em 1924, em São Paulo. Com duração de apenas um dia, o movimento tenentista de 1922 tinha o intuito de modernizar o Brasil, lutar pelo fim da corrupção governista, combater as desigualdades sociais e enfrentar a concentração de poder em prejuízo das imensas maiorias do povo.

Um dos principais motivos que fizeram a Revolta ocorrer foi o episódio das cartas falsas que acabou cumprindo o seu papel de lançar as Forças Armadas contra a candidatura à Presidência da República do mineiro Artur Bernardes, representante das mazelas da política do café com leite. Neste conflito, antes de Bernardes assumir, o presidente Epitácio Pessoa saiu vitorioso, foi decretado o mais longo período de estado de sítio que o país foi submetido, encobrindo perseguições políticas a qualquer indivíduo que simpatizasse com os revolucionários.

No que diz respeito ao personagem principal desta história, o autor nos revela alguns fatos muito interessantes de Côrrea, como por exemplo, seu envolvimento com líderes tenentistas, bem antes do confronto final.

Em meio a organização do movimento revolucionário, no dia 4 de julho de 1922, os revolucionários perceberam que alguns conspiradores foram identificados após contato pelo telefone com o Forte de Copacabana. Assim, o comandante Euclydes Hermes, suspeitando de que a linha estava sob escuta da Polícia Política, foi convencido pelo tenente Siqueira Campos a aceitar a sugestão de Corrêa, de puxar diretamente um par de fios como extensão do 
telefone do cabaré Mère Louise, que ficava próximo ao Forte de Copacabana, até a sala de comando do mesmo, sendo que a linha do Forte sob escuta deveria ser evitada.

Por meio da obra, percebemos que o personagem se sentia à vontade no Rio de Janeiro, gostando muito de frequentar o Mère Louise, sentando sempre em uma mesa na varanda do cabaré, de frente para o mar de Copacabana. Era uma pessoa muita generosa, insistindo sempre em pagar a parte maior da conta. Corrêa também era muito querido pelos oficiais que frequentavam a boate, pois tinha bom humor, conhecimento de música e contava muitas histórias de aventura, apesar das provocações políticas. Devido a tais provocações, Euclydes Hermes da Fonseca havia proibido seus homens das discussões políticas no cabaré.

Um fato curioso, é que de todos os militares, o comandante do Forte de Copacabana era o que conhecia Corrêa há mais tempo e foi quem o apresentou aos oficiais, ressaltando sobre sua lealdade. Eles não se conheceram no Mère Louise e sim bem antes, devido ao relacionamento entre seus pais, o marechal Hermes e Carlos Alberto Corrêa, que conviveram como amigos gaúchos do senador Pinheiro Machado.

Corrêa era um homem muito rico, gostava de contar histórias sobre sua família e de como havia conquistado sua fortuna. Tinha decidido não se casar para não acabar cedendo à pressão do pai que o queria no campo, trabalhando como cabanheiro. Buscava diversão e mulheres, gastando e aproveitando o conforto.

Sua mãe se chamava Leopoldina, apelidada de Dona Pudica, sempre educando seus filhos de forma muito rígida. Côrrea também tinha quatro irmãos, o mais velho era chamado de Joca, tinha estudado em Pelotas com os jesuítas da escola São Luís Gonzaga. Gregório, outro irmão, foi para o Colégio Anchieta, na capital.

Com relação ao personagem, aos dez anos de idade foi enviado para a fronteiriça Quaraí à cidade de São Leopoldo, para estudar como interno no Colégio de Nossa Senhora da Conceição, onde acabou pegando gosto por Francês, Matemática e Música. Habilitou-se em Francês no terceiro ano da Escola Brasileira, na Rua Duque de Caxias, número 229, em Porto Alegre. Também estudavam nessa escola, os seus irmãos Adalberto e Carlos Zaccharias, além do amigo Getúlio Vargas.

Com relação aos principais acontecimentos da sublevação de 1922, Côrrea, no dia 6 de julho, por volta das 11 horas, do telefone do cabaré ligou para o Forte para saber o que estava acontecendo. Do outro lado da linha, o tenente Mário Carpenter atendeu e informou que havia uma trégua, tendo o comandante saído para negociar as condições de armistício com o ministro da Guerra. Carpenter pediu a Corrêa que o telefone ficasse livre, pois estavam aguardando as notícias que o capitão mandaria do Catete.

No final da manhã, Corrêa foi até o Forte de Copacabana, o tenente Newton Prado deixou o civil entrar, após os cumprimentos pela coragem, Siqueira Campos chamou Corrêa para ficar ao seu lado. Antes de sair do Forte, foi feita a contagem dos revolucionários, totalizando 28, contando com o civil.

Com o objetivo de aliviar a tensão, o tenente Carpenter riscou as paredes internas do Forte com pregos e baionetas para registrar os nomes dos que permaneceram. Havia no Forte 
de Copacabana uma bandeira do Brasil que foi cortada em 28 pedaços e entregue a cada membro que lá haviam ficado. Ao mesmo tempo, Corrêa recebeu de Siqueira Campos o pedaço da bandeira do Brasil destinado ao capitão Euclydes, que a esta altura já se encontrava preso. Ao sair do Forte, os 28 combatentes se reduziram para 18, depois, ao marcharem na altura da Praça Serzedelo, reduziram-se para 12.

Ao marchar junto com os tenentes pela calçada ondulada de Copacabana, Corrêa vestia um paletó e levava um fuzil Mauser na mão. Durante a troca de tiros, conseguiu acertar alguns adversários das tropas do governo, entre eles o sargento Narciso Baptista, até que um projétil de fuzil the atingiu o peito, levando-o a cair no mesmo instante. Segundo Licks o civil foi conduzido vivo ao hospital militar, resistindo até às 19 horas, quando veio a falecer de hemorragia.

Analisando a obra em si, observamos que ela apresenta um conteúdo inédito sobre a vida de Corrêa. Contudo, Licks tenta construir uma biografia heroica do personagem, destacando que desde criança já era uma pessoa diferenciada, como se seu destino já tivesse predestinado. Outra crítica que pode ser feito a obra é que o autor mescla um pouco de fato histórico e ficção, o que às vezes deixa a obra a desejar. Todavia, o livro é importante pelo fato de revelar outras facetas da insurreição tenentista de 1922 , pois o que sabíamos até então, era que Corrêa foi apenas um civil que aceitou participar de última hora da marcha para a morte na calçada de Copacabana. Assim, a obra revela mais do que isso e nos mostra que o personagem já tinha uma relação com os principais tenentes e inclusive os auxiliaram nos preparativos para a Revolta. Além do mais, o livro é um atrativo para os historiadores que desejam realizar um futuro trabalho sobre a trajetória do personagem. 